\title{
EVALUASI TERHADAP RUMUSAN RUU PERMUSIKAN
}

\author{
Binsar A. Hutabarat \\ Reformed Center for Religion and Society
}

\begin{abstract}
This article entitled "Evaluation of the Draft Music Bill" focuses on the substance of the problem set out in the Music Bill, and the procedural side of drafting the Music Bill as an alternative policy, namely "the process of drafting a policy as seen from the parties involved in its formulation (policies stakeholders). This policy research is a type of research on the evaluation of policy formulation. The findings of this paper are that the Music Bill, specifically related to the process of its formulation, does not involve adequate stakeholders, and the substance of the policy formulation, specifically regarding the rules of the creative process, has been limiting individual freedom. The drafting of the Music Bill lacks proper attention to the boundaries of private space and public space. The author's recommendation is that the discussion on the Music Bill as an alternative public policy program should be stopped.
\end{abstract}

KEYWORDS: policy, public policy, policy evaluation, music bill.

ABSTRAK: Artikel yang berjudul "Evaluasi terhadap Rancangan Undang-Undang Permusikan" ini fokus pada substansi masalah yang dituangkan dalam RUU Permusikan, serta sisi prosedural perumusan RUU Permusikan sebagai alternatif kebijakan, yakni proses penyusunan suatu kebijakan dilihat dari pihak-pihak yang terlibat dalam perumusannya (policies stakeholders). Penelitian kebijakan ini merupakan jenis penelitian evaluasi rumusan kebijakan. Temuan tulisan ini adalah RUU Permusikan, secara khusus terkait proses perumusannya tidak melibatkan stakeholder yang memadai, dan substansi rumusan kebijakan itu, secara khusus tentang aturan proses kreatif terindikasi telah membatasi kebebasan individu. Perumusan RUU Permusikan kurang 
memerhatikan batasan ruang privat dan ruang publik secara tepat. Rekomendasi penulis adalah RUU Permusikan sebagai alternatif kebijakan publik permusikan harus dihentikan pembahasannya sebagai alternatif kebijakan publik permusikan.

KATA-KATA KUNCI: kebijakan, kebijakan publik, evaluasi kebijakan, undang-undang permusikan.

\section{Pendahuluan}

Kebijakan publik yang unggul sejatinya dapat diimplementasikan dengan baik untuk menghadirkan kehidupan publik yang sehat, damai dan sejahtera. Implementasi kebijakan dapat dilaksanakan karena mereka yang menjadi sasaran kebijakan tersebut bergairah untuk melaksanakannya. Gairah masyarakat untuk mengimplementasikan kebijakan yang unggul dapat dipahami karena kebijakan tersebut disambut oleh mereka yang menjadi sasaran kebijakan sebagai jawaban terhadap persoalan mereka. Dengan demikian dapat dipahami bahwa hadirnya kebijakan publik yang unggul haruslah melalui proses yang benar dan melibatkan stakeholder yang memadai.

Hadirnya kebijakan-kebijakan yang menuai protes masyarakat luas di Indonesia seharusnya memberi kesadaran pada elite politik penyusun kebijakan bahwa ada yang salah dalam perumusan kebijakan publik tersebut. Hal ini juga terjadi pada RUU Permusikan.

Kehadiran RUU Permusikan yang telah masuk dalam daftar Program Legislasi Nasional (Prolegnas) tahun 2019 bukannya disambut gembira, sebaliknya telah menuai demonstrasi dari berbagai kelompok yang merasa dirugikan. Koalisi Nasional Tolak Rancangan UndangUndang Permusikan mengumumkan bahwa RUU Permusikan itu memiliki sejumlah permasalahan terkait dengan substansi kebijakan serta adanya disharmoni dengan perundang-undangan lain. Selain substansi kebijakan yang menjadi dasar penolakan, terindikasi bahwa 
perumusan kebijakan tersebut tidak menyertakan para pekerja musik. ${ }^{1}$

Mengingat kehadiran sebuah kebijakan publik sangat strategis dan berdampak luas, dan belum banyak yang menyorotinya secara akademis, maka kajian ini akan mengevaluasi proses perumusan agenda kebijakan sebagaimana tertuang dalam RUU Permusikan dan substansi dari RUU Permusikan. Penelitian kebijakan ini merupakan jenis penelitian kebijakan substantif dengan fokus pada substansi masalah yang dituangkan dalam RUU Permusikan, serta sisi prosedural perumusan RUU Permusikan sebagai alternatif kebijakan, yakni proses penyusunan suatu kebijakan dilihat dari pihak-pihak yang terlihat dalam perumusannya (policies stakeholders).

\section{Publik dan Privat}

Ide tentang kebijakan publik sesungguhnya menyiratkan adanya domain publik, suatu ruang yang bukan privat, tetapi milik umum atau milik bersama. Pemisahan domain publik dan domain privat terus menjadi perdebatan hingga saat ini. Perdebatan itu wajar terjadi karena batasan mana yang menjadi domain privat dan domain publik tidaklah sederhana. Batasan mana domain privat dan domain publik sesungguhnya merupakan tema abadi yang terus menjadi perdebatan hingga saat ini. Saxonhouse tepat ketika menjelaskan bahwa tidak ada konsepsi yang seragam tentang hubungan antara kedua ruang tersebut. ${ }^{2}$

Wayne Parsons menjelaskan bahwa ruang publik adalah ruang aktivitas manusia yang dipandang perlu diatur atau diintervensi oleh pemerintah atau aturan sosial, atau setidaknya aturan bersama yang dihasilkan dari konsensus bersama. ${ }^{3}$ Hal ini berarti bahwa sebuah kebijakan publik yang unggul hanya mungkin hadir jika semua elemen publik yang menjadi sasaran kebijakan dilibatkan dan penyusun

\footnotetext{
"RUU Permusikan Prematur", Kompas, Kamis, 7 Februari 2019.

Wayne Parsons, Public Policy (Jakarta: Prenadia Group, 2014), 4-5.

Ibid.
} 
kebijakan memiliki pemahaman ruang publik dan privat yang jelas. Karena itu, perumusan kebijakan publik yang tidak dilakukan dengan hati-hati bukannya memberikan jalan keluar terhadap persoalan publik, sebaliknya akan menimbulkan masalah baru.

Resolusi konflik ruang privat dan publik pada awalnya terdapat dalam gagasan Aristoteles mengenai "polis" sebagai bentuk tertinggi dari asosiasi manusia. Usaha untuk menengahi ketegangan antara publik dan privat terus berlanjut hingga saat ini. Pandangan yang menetapkan perbedaan yang jelas antara kekuasaan publik dan dunia privat berpendapat bahwa peran negara adalah menciptakan kondisi di mana kepentingan publik dapat terjamin. Pemerintah dalam hal ini lebih baik tidak terlalu campur tangan dalam ruang publik. Menurut pandangan ini, kepentingan publik akan terlayani dengan baik apabila kepentingan kebebasan ekonomi dan pasar difasilitasi oleh negara, bukannya dibatasi atau diatur oleh negara. Mekanisme pasar dalam hal ini menjadi pengatur ruang publik. ${ }^{4}$

Gagasan mengenai perbedaan yang tegas antara ruang publik dan privat ternyata mulai runtuh sejak abad ke-19. Penetrasi kebijakan publik ke dalam ruang yang oleh para ahli ekonomi disebut sebagai ruang privat mulai terjadi di hampir semua bidang kehidupan sosial. Perumusan kebijakan publik pada saat ini memerlukan keterlibatan yang lebih luas dari sebelumnya, dan tidak hanya terbatas pada lembaga eksekutif dan legislatif. Perumusan kebijakan publik memerlukan keikutsertaan semua pihak agar kebijakan yang dilahirkan adalah kebijakan yang baik untuk semua, dalam hal ini ahli-ahli kebijakan memainkan peran strategis.

\section{Kebijakan Publik}

Istilah policy (kebijakan) berasal dari bahasa Yunani "polis" (negara-kota) dan bahasa Sansekerta "pur" (kota), dikembangkan dalam bahasa Latin

4 Ibid. 
menjadi "politia" (negara), dalam bahasa Inggris "policie", yang berarti menangani masalah-masalah publik atau administrasi pemerintahan. Asal-usul etimologis kata policy sama dengan dua kata penting lainnya: police dan politics. Inilah salah satu alasan mengapa banyak bahasa modern, misalnya Jerman dan Rusia hanya mempunyai kata (politik, politika) untuk dua pengertian (policy dan politics) Ini juga merupakan salah satu faktor yang saat ini menimbulkan kebingungan seputar batas disiplin ilmu politik, administrasi negara, dan ilmu kebijakan, semuanya menaruh perhatian besar pada studi politik (politics) dan kebijakan (policy). ${ }^{5}$

Menurut Harold Lasswell: "Kata “kebijakan” (policy) umumnya dipakai untuk menunjukkan pilihan terpenting yang diambil baik dalam kehidupan organisasi atau privat." 6 Berdasarkan penjelasan Lasswell dapat dipahami, bahwa Lasswell tidak membatasi penggunaan istilah kebijakan hanya dalam area politik saja, menurutnya, "Kebijakan" bebas dari konotasi yang dicakup dalam kata politis (political) yang sering kali diyakini mengandung makna "keberpihakan" dan "korupsi".7

Meski istilah kebijakan (policy) adalah istilah yang digunakan secara luas, namun Parsons berpendapat bahwa, "istilah kebijakan tepatnya digunakan untuk sesuatu yang 'lebih besar' ketimbang keputusan tertentu, tetapi lebih kecil ketimbang gerakan sosial." ${ }^{8}$ Sejalan dengan Parsons, Budi Winarno menerangkan, secara umum istilah "kebijakan" atau "policy" digunakan untuk menunjuk perilaku seorang aktor atau sejumlah aktor dalam suatu bidang tertentu. ${ }^{9}$ Selanjutnya Winarno sejalan dengan Parsons menjelaskan, pengertian kebijakan hanya memadai untuk keperluan pembicaraan biasa atau umum, namun

\footnotetext{
5 William N. Dunn, Pengantar Analisis Kebijakan (Yogyakarta: Gadjah Mada University Press, 2013), 51.

6 Ibid., 17.

7 Ibid.

8 Wayne Parsons, Public Policy (Jakarta: Kencana, 2006), 14.

9 Budi Winarno, Kebijakan Publik: Teori, Proses, dan Studi Kasus (Jakarta: Center of Academic Publishing Service, 2007), 19.
} 
menjadi kurang memadai untuk pembicaraan-pembicaraan yang lebih bersifat ilmiah dan sistematis menyangkut analisis kebijakan publik. ${ }^{10}$

Wayne Parsons lebih jauh menerangkan makna modern dari gagasan "kebijakan" dalam bahasa Inggris adalah seperangkat aksi atau rencana yang mengandung tujuan politik yang berbeda dengan makna "administration". Yang lebih penting khususnya sejak periode pascaPerang Dunia II, kata policy mengandung makna kebijakan sebagai sebuah rationale, sebuah manifestasi dari penilaian yang penuh pertimbangan. Singkatnya, sebuah kebijakan adalah usaha mendefinisikan dan menyusun basis rationale untuk melakukan atau tidak melakukan sesuatu. ${ }^{11}$

Makna kata kebijakan secara lebih mendalam dapat lebih dipahami dengan memahami konteks historis istilah kebijakan, makna kebijakan yang senantiasa berubah menunjukkan perubahan-perubahan dalam praktik kebijakan. Parsons lebih lanjut mengungkapkan, di Inggris, (policy) mengandung makna yang kompleks dan beragam. Dalam karya Shakespeare, misalnya kita menjumpai empat makna yang berbeda: kehati-hatian, sebentuk pemerintahan, tugas, dan administrasi, serta sebagai "machiavellianisme". Kebijakan mencakup seni ilusi politik dan duplikasi. Penonjolan, penampilan luar dan tipuan (illusion) adalah beberapa unsur yang membentuk kekuasaan (power). Shakespeare menggunakan istilah filsafat Machiavellian; dan policy menunggangi kesadaran, demikian dikatakan sang penyair dalam Timon of Athens. ${ }^{12}$

Pada awalnya istilah "kebijakan" atau pokok-pokok platform menjadi rasionalitas politik. Mempunyai kebijakan berarti memiliki alasan atau argumen yang mengandung klaim bahwa pemilik kebijakan memahami persoalan beserta solusinya. Kebijakan memberikan semacam teori yang mendasari klaim legitimasi. Selanjutnya, dengan

\footnotetext{
$10 \quad$ Ibid., 19.

11 Wayne Parsons, op. cit., 15.

12 Ibid., 16.
} 
berkembangnya sistem partai dan pemilu modern di masyarakat industri, diskursus kebijakan kemudian menjadi sarana utama bagi elektorat untuk terlibat dalam kegiatan "politik" dan persaingan elite politik. Dalam konteks tersebut di atas, politisi dituntut memiliki "kebijakan" sebagaimana halnya sebuah toko mesti mempunyai barang dagangan. Dalam area itu, kebijakan merupakan "mata uang" penting dalam perdagangan demokratik. ${ }^{13}$

Berdasarkan paparan di atas jelaslah bahwa sebuah kebijakan publik sejatinya menjadi jawaban bagi persoalan masyarakat, sebuah strategi pemerintah untuk membawa masyarakat pada cita-cita kemerdekaan yang telah disepakati bersama. Kebijakan publik merupakan upaya yang dilakukan pemerintah untuk menyelesaikan permasalahan publik. Thomas R. Dye merangkum dari definisi-definisi mengenai kebijakan publik demikian: "Public policy is whatever governments choose to do or not to do"14. Kebijakan publik tidak hanya pada apa yang dilakukan pemerintah (misalnya melalui penyusunan undangundang) melainkan termasuk juga apa saja yang tidak dilakukan oleh pemerintah. Karena hal-hal yang tidak dilakukan pemerintah menurutnya juga mempunyai dampak yang cukup besar terhadap masyarakat seperti halnya dengan tindakan-tindakan yang tidak dilakukan oleh pemerintah. ${ }^{15}$

Tindakan pemerintah untuk tidak intervensi di ruang publik untuk terjaganya kehidupan publik yang sehat juga merupakan kebijakan pemerintah, karena keputusan untuk tidak intervensi pada ruang publik adalah sebuah kebijakan pemerintah. Untuk menciptakan ruang publik yang sehat pemerintah tidak harus melahirkan sebuah undang-undang, apalagi jika intervensi pemerintah melalui kebijakan publik itu dapat membelenggu kebebasan individu-individu dalam

\footnotetext{
Ibid., 16.

14 Thomas R. Dye, Understanding Public Policy (United States: Prentice Hall, 1978), 1.

15 Irawan Suntoro dan Hasan Hariri, Kebijakan Publik (Yogyakarta: Graha Ilmu, 2015), 3.
} 
ruang publik.

Kebijakan publik sebagai sesuatu yang dikerjakan pemerintah juga ditegaskan oleh James E. Anderson, "Public policies are those policies developed by governmental bodies and officials."16 Menurut Anderson kebijakan merupakan arah tindakan yang mempunyai maksud yang ditetapkan oleh seorang aktor atau sejumlah aktor dalam mengatasi suatu masalah atau suatu persoalan. ${ }^{17}$

Berdasarkan definisi-definisi di atas dapat dipahami, bahwa kebijakan publik mempunyai beberapa implikasi sebagaimana ditegaskan Anderson, kebijakan publik berorientasi pada maksud atau tujuan, bukan perilaku serampangan. Kebijakan publik bukan sesuatu yang berlaku begitu saja, melainkan direncanakan oleh aktor-aktor politik yang terlibat dalam sistem politik. Kebijakan merupakan arah atau pola tindakan yang dilakukan oleh pejabat-pejabat pemerintah, dan bukan merupakan keputusan-keputusan tersendiri.

Suatu kebijakan mencakup tidak hanya keputusan untuk menetapkan undang-undang mengenai suatu hal, tetapi juga keputusankeputusan beserta dengan pelaksanaannya. Kebijakan publik dalam bentuknya dapat bersifat positif dan negatif. Secara positif, kebijakan, mungkin mencakup bentuk tindakan pemerintah yang jelas untuk memengaruhi suatu masalah tertentu. Secara negatif, kebijakan mungkin mencakup suatu keputusan oleh pejabat-pejabat pemerintah, tetapi tidak untuk mengambil keputusan tindakan dan tidak untuk melakukan sesuatu mengenai suatu persoalan yang memerlukan keterlibatan pemerintah. Dengan kata lain, pemerintah dapat mengambil kebijakan untuk tidak melakukan campur tangan dalam bidang-bidang umum maupun khusus. Kebijakan tidak campur tangan mungkin mempunyai konsekuensi-konsekuensi besar terhadap masyarakat atau kelompokkelompok masyarakat. Dalam bentuknya yang positif, kebijakan publik

16 Sahya Anggara, Kebijakan Publik (Bandung: Pustaka Setia, 2014), 35.

17 Edi Suharto, Analisis Kebijakan Publik (Bandung: Alfa Beta, 2005), 21. 
didasarkan pada undang-undang dan bersifat otoritatif. ${ }^{18}$

Dengan demikian jelaslah bahwa kebijakan publik adalah jalan bagi pemerintah untuk mencapai apa yang dicita-citakan seluruh rakyat. Kebijakan publik adalah pedoman bagi sebuah negara untuk mencapai apa yang diperintahkan konstitusi. ${ }^{19}$

Peraturan Menteri Negara Pendayagunaan Aparatur Negara Nomor: Per/04/M.PAN/4/2007 tentang Pedoman Umum Formulasi, Implementasi, Evaluasi Kinerja, dan Revisi Kebijakan Publik di Lingkungan Lembaga Pemerintah Pusat dan Daerah mendefinisikan kebijakan publik adalah keputusan yang dibuat oleh pemerintah atau lembaga pemerintahan untuk mengatasi masalah tertentu, untuk melakukan kegiatan tertentu atau untuk mencapai tujuan tertentu yang berkenaan dengan kepentingan dan manfaat orang banyak.

\section{Proses Kebijakan Publik}

Orang pertama yang menggambarkan ide public policy dapat dipelajari secara sistematik adalah John Dewey. Di dalam bukunya Logic: The Theory of Inquiry, Dewey memberikan perhatian terhadap sifat eksperimen dari cara mengukur kebijaksanaan (policy). Digambarkan pula bagaimana rencana-rencana tindakan harus dipilih dari alternatif-alternatif dan bagaimana mengamati akibat-akibat yang dapat dipergunakan sebagai uji coba yang tepat. ${ }^{20}$

Buah pikiran Dewey tersebut diambil oleh Harold Lasswell, seorang eksperimentalis ilmu politik yang pertama kali mempertajam ide ilmu policy sebagai suatu disiplin yang tidak terpisahkan dari disiplindisiplin ilmu lainnya. Menurutnya, ilmu kebijakan adalah studi tentang proses pembuatan keputusan atau proses memilih dan mengevaluasi informasi yang tersedia dan bergayutan untuk memecahkan masalah-

\footnotetext{
18 Budi Winarno, op. cit., 23-4.

19 Fuad Ihsan, Dasar-Dasar Kependidikan (Jakarta: Rineka Cipta, 2011), 121.

20 Miftah Thoha, Ilmu Administrasi Publik Kontemporer (Jakarta: Prenadamedia Group, 2015), 104.
} 
masalah tertentu. Ilmu seperti ini adalah memusatkan pada lima tugas intelektual di dalam memecahkan persoalan. Lima tugas intelektual tersebut antara lain: penjelasan tujuan-tujuan, penguraian kecenderungan-kecenderungan, penganalisisan keadaan, proyeksi dari pengembangan masa depan, dan penelitian, evaluasi dan penelitian, evaluasi dan pemilihan alternatif. ${ }^{21}$

Proses pembuatan kebijakan publik merupakan proses yang kompleks karena melibatkan banyak proses maupun variabel yang harus dikaji. Oleh karena itu, beberapa ahli politik yang menaruh minat untuk mengkaji kebijakan publik membagi proses-proses penyusunan kebijakan publik ke dalam beberapa tahap. Tujuan pembagian seperti ini adalah untuk memudahkan mengkaji kebijakan publik. ${ }^{22}$ Pembuatan putusan kebijakan (policy decision making) adalah hasil sebuah proses pemilihan alternatif terbaik dari sejumlah alternatif yang tersedia. Sebagai bagian dari pembuatan, maka pembuatan keputusan adalah hasil tindakan yang dapat terlihat pada tujuan tertentu, yang dilakukan oleh seorang aktor atau sejumlah aktor yang dapat terlihat dalam setiap tahapan dan proses kebijakan publik yang dilakukan. Karenanya pembuatan keputusan haruslah merupakan tindakan terpola dari aktor, menggunakan model dan teknik yang tepat, dan dilakukan sepanjang waktu dan melibatkan banyak keputusan sehingga hasilnya adalah lahirnya kebijakan yang berdimensi rasional yang substantif, dan diharapkan dapat menyelesaikan persoalan kepublikan secara cerdas, bijaksana, dan memberikan harapan. ${ }^{23}$

Lokus pembuatan keputusan kebijakan (policy decision making) berada di antara fase perumusan kebijakan dan implementasi, di mana kedua hal tersebut saling terkait satu sama lain. Keputusan memengaruhi implementasi, dan implementasi tahap awal akan

\footnotetext{
$21 \quad$ Ibid., 104.

22 Budi Winarno, Kebijakan Publik, 35.

23 Novita Tresina, Rasionalitas dan Pembuatan Keputusan Kebijakan (Yogyakarta: Graha Ilmu, 2015), 15.
} 
memengaruhi implementasi berikutnya. Pembuatan keputusan bukanlah proses pasif, melainkan sebuah proses, dan keputusan awal sering kali hanya merupakan sinyal petunjuk arah atau dorongan awal, atau percobaan awal, yang nantinya akan mengalami revisi dan diberi spesifikasi.

\section{Rumusan RUU Permusikan}

Berdasarkan naskah akademik RUU Permusikan dan RUU Permusikan dapat dipahami bahwa yang menjadi tujuan dari hadirnya RUU tersebut adalah: a. bahwa musik sebagai bagian dari budaya berfungsi sebagai perekam nilai kehidupan dan jejak sejarah peradaban bangsa Indonesia serta menjadi aset penting dalam pemajuan kebudayaan perlu dipelihara, dilestarikan, dan dikembangkan; b. bahwa saat ini masih terdapat permasalahan dalam permusikan yang terkait dengan penyelenggaraan, perlindungan, dan pendataan serta pengarsipan sehingga perlu dilakukan penataan yang komprehensif agar permusikan dapat berkembang secara berkesinambungan dan memberikan manfaat bagi kemajuan bangsa; c. bahwa peraturan perundang-undangan yang ada belum mampu memenuhi perkembangan hukum dan dinamika masyarakat sehingga diperlukan payung hukum yang dapat mewujudkan penyelenggaraan permusikan yang baik dan memberikan kepastian hukum; d. bahwa berdasarkan pertimbangan sebagaimana RUU Permusikan dimaksud dalam huruf a, huruf b, dan huruf c, perlu membentuk Undang-Undang tentang Permusikan;24

Dasar hukum dari penyusunan Undang-Undang Permusikan adalah Pasal 20, Pasal 21, dan Pasal 32 ayat (1) Undang-Undang Dasar Negara Republik Indonesia Tahun 1945. Artinya, RUU permusikan ini adalah usulan dari Badan Perwakilan Rakyat yang memang memiliki hak

\footnotetext{
24 Naskah Akademik RUU Permusikan (Tim Penyusun RUU tentang Permusikan Pusat Perancangan Undang-Undang Badan Keahlian Dewan Perwakilan Rakyat Republik Indonesia 2018).
} 
dalam penyusunan undang-undang. Sedangkan Pasal 32 ayat (1) berbunyi: Setiap orang berhak mengembangkan diri melalui pemenuhan kebutuhan dasarnya, berhak mendapat pendidikan dan memeroleh manfaat dari ilmu pengetahuan dan teknologi, seni dan budaya, demi meningkatkan kualitas hidupnya dan demi kesejahteraan umat manusia. 25

Kronologis hadirnya RUU Permusikan dalam Program Legislasi Nasional 2019 adalah seperti berikut; Pada 7 Juni 2017 para musisi dan pemangku kepentingan industri musik secara resmi menyampaikan usulan RUU tentang Permusikan kepada Badan Legislasi (Baleg) DPR RI. Naskah akademik RUU Permusikan melaporkan bahwa usulan dihadirkannya UU Permusikan adalah untuk memajukan dunia permusikan Indonesia, sekaligus juga memajukan kebudayaan nasional Indonesia. Pada 15 Agustus 2018 RUU Permusikan ini dianggap perlu oleh Dewan Perwakilan Rakyat untuk mengakomodasi kebutuhan dunia permusikan di Indonesia. Baleg DPR menyatakan komitmennya untuk mendorong agar RUU ini dapat dimasukkan ke dalam Program Legislasi Nasional (Prolegnas). DPR RI melalui Komisi X kemudian merencanakan untuk menyusun RUU tentang Permusikan, dengan menugaskan Badan Keahlian DPR RI untuk menyusun konsep naskah akademik dan RUU tentang Permusikan. ${ }^{26}$

Naskah Akademik RUU Permusikan menerangkan bahwa Tim Penyusun telah mendapatkan pandangan dan masukan dari pemangku kepentingan yang terkait dengan penyelenggaraan permusikan. Penyusunan Naskah Akademik RUU tentang Permusikan dilakukan melalui studi kepustakaan/literatur dengan menelaah berbagai data 15 Agustus 2018 sekunder seperti peraturan perundang-undangan terkait, baik di tingkat undang-undang maupun peraturan pelaksanaan dan berbagai dokumen hukum terkait. Guna melengkapi studi kepustakaan

\footnotetext{
25 Ibid.

26 Ibid.
} 
dan literatur dilakukan pula diskusi melalui Focus Group Discussion/FGD dan wawancara serta kegiatan uji konsep dengan berbagai pihak berkepentingan atau stakeholders terkait permusikan dan para pakar atau akademisi.

Substansi RUU Permusikan diyakini sebagai solusi terhadap permasalahan kurangnya keseimbangan/balancing antara perkembangan musik tradisional dan musik modern. Perkembangan musik tradisional cenderung menurun sebagai akibat kurangnya perhatian dari pemerintah, khususnya pemerintah daerah. Padahal, menurut naskah akademik RUU tersebut, idealnya musik tradisional yang merupakan local genus harus dilestarikan dan dikembangkan, termasuk mendapat advokasi dari pemerintah. Selanjutnya juga dijelaskan, tata kelola musik Indonesia saat ini masih tergantung sepenuhnya kepada mekanisme pasar dan menitikberatkan pada pop culture, sehingga jenis musik lainnya, terutama musik tradisional, kurang mendapatkan perhatian. Idealnya perlu dibedakan antara tata kelola industri musik dengan musik tradisional. Artinya RUU Permusikan menginginkan adanya intervensi pemerintah berupa undang-undang untuk memajukan musik tradisonal dan tata kelola industri musik.

RUU tentang Permusikan itu memiliki cakupan yang luas mengenai penyelenggaraan permusikan, mulai dari proses kreasi, reproduksi, distribusi, dan konsumsi. Selain itu, diatur pula mengenai perlindungan terhadap karya musik dan pelaku musik, pengembangan pelaku musik melalui pendidikan dan apresiasi, sistem pendataan dan pengarsipan, serta partisipasi masyarakat dalam penyelenggaraan permusikan.

Berdasarkan penjelasan di atas dapat dipahami bahwa perumusan RUU Permusikan merupakan inisiatif DPR, dan diakui bahwa perumusan tersebut lebih kepada ide-ide yang lahir dari Dewan Perwakilan Rakyat, dan tidak didasarkan atas riset yang mendalam tentang persoalan terkait dengan permusikan, apalagi cakupan RUU itu sangat luas. 
Pasal kontroversial yang mendapat penolakan luas tertuang dalam pasal 50 yang menjelaskan bahwa Setiap orang yang dengan sengaja melakukan Proses Kreasi yang mengandung unsur: a. mendorong khalayak umum melakukan kekerasan dan perjudian serta penyalahgunaan narkotika, psikotropika, dan zat adiktif lainnya; $b$. memuat konten pornografi, kekerasan seksual, dan eksploitasi anak; c. memprovokasi terjadinya pertentangan antarkelompok, antarsuku, antarras, dan/atau antargolongan; d. menistakan, melecehkan, dan/atau menodai nilai agama; e. mendorong khalayak umum melakukan tindakan melawan hukum; f. membawa pengaruh negatif budaya asing; dan/atau RUU Permusikan g. merendahkan harkat dan martabat manusia. ${ }^{27}$

\section{Evaluasi Proses Perumusan RUU Permusikan}

Berdasarkan kronologis penyusunan RUU Permusikan yang telah dipaparkan dalam naskah akademiknya dapat diketahui bahwa RUU tersebut merupakan usulan DPR. Adapun yang mendasari usulan tersebut adalah belum adanya undang-undang yang mengatur tentang permusikan. Kenyataan tersebut menjadi dasar bagi anggota DPR untuk merumuskan undang-undang yang mengatur permusikan. Tujuannya adalah agar dengan adanya undang-undang permusikan itu ada kepastian hukum bagi pemerintah untuk mengatur tentang permusikan untuk kemudian mengembangkan dunia permusikan di Indonesia yang dijelaskan dalam RUU tersebut bahwa musik tradisional tertinggal dari musik-musik lain yang berasal dari luar negeri. Dengan demikian dapat dipahami bahwa penyusun undang-undang beranggapan intervensi pemerintah untuk memajukan permusikan harus didasari dengan adanya undang-undang. Dengan kata lain, RUU Permusikan merupakan produk DPR untuk memajukan permusikan Indonesia.

$27 \quad$ Ibid. 
Pemikiran bahwa pemerintah hanya dapat intervensi untuk memajukan permusikan di Indonesia dengan menghadirkan RUU Permusikan menunjukkan kurang pahamnya pemerintah mengenai kebijakan publik. Karena apapun yang pemerintah lakukan terhadap dunia permusikan, baik secara positif yakni dengan menghadirkan RUU Permusikan atau secara negatif dengan tidak menghadirkan undangundang, keduanya merupakan kebijakan. DPR harus memahami bahwa adakah problem khusus yang mengharuskan hadirnya sebuah undangundang untuk mengatur kehidupan publik terkait permusikan? Pada saat yang sama juga DPR harus memahami apakah kebijakan publik itu telah bergerak jauh pada dunia privat atau tidak. Maraknya demonstrasi terkait kebijakan tersebut menjelaskan bahwa ada ruang privat yang telah diintervensi kebijakan publik itu. Kebijakan DPR bisa juga mencakup suatu keputusan untuk mengambil keputusan untuk melakukan sesuatu mengenai suatu persoalan yang memerlukan keterlibatan pemerintah. Dengan kata lain, DPR dapat mengambil kebijakan untuk tidak melakukan campur tangan dalam bidang-bidang umum maupun khusus. Kebijakan tidak campur tangan DPR mungkin mempunyai konsekuensi-konsekuensi besar untuk memajukan permusikan di Indonesia. DPR harusnya memerhatikan apa yang dikatakan Thomas R. Dye, kebijakan publik adalah apa yang dilakukan pemerintah dan apa yang tidak dilakukan pemerintah. Intervensi pemerintah dalam ruang publik tidak harus berupa undang-undang, menjaga kebebasan individu agar tercipta ruang publik yang sehat tidak harus dilakukan dengan undang-undang.

Mengamati agenda permasalahan yang tertuang dalam RUU Permusikan terlihat adanya ketidakjelasan mengenai agenda permasalahan. Ketidakjelasan ini dapat dipahami bahwa RUU permusikan tidak didasarkan pada riset mendalam sebagaimana seharusnya sebuah kebijakan publik. Riset kepustakaan dan penggunaan Focus Goup Discussion (FGD) yang melibatkan lembaga-lembaga permusikan hanya sebatas sosialisasi dari rumusan akademik. Lemahnya 
perumusan agenda permasalahan tentang permusikan dapat terlihat juga dari waktu penelitian yang sangat singkat, sekitar satu tahun, termasuk sosialisasi yang melibatkan lembaga-lembaga permusikan. Padahal, sebuah proses penyusunan agenda publik permusikan tidak terlepas dari kepentingan politik yang saling bertarung, sebagaimana dijelaskan William N. Dunn, tahapan proses kebijakan publik haruslah didahului sebuah fase dan proses yang sangat strategis dalam realitas kebijakan publik. Dalam proses inilah pembuat keputusan memiliki ruang untuk memaknai apa yang disebut sebagai masalah publik dan prioritas dalam agenda publik yang dipertarungkan. Jika sebuah isu berhasil mendapatkan status sebagai masalah publik, dan mendapatkan prioritas dalam agenda publik, maka isu tersebut berhak mendapatkan alokasi sumber daya publik yang lebih daripada isu lain. Selanjutnya, masih menurut William N. Dunn, masalah yang sudah masuk dalam agenda kebijakan kemudian dibahas oleh para pembuat kebijakan. Masalahmasalah tadi didefinisikan untuk kemudian dicari pemecahan masalah yang terbaik. Pemecahan masalah tersebut berasal dari berbagai alternatif atau pilihan kebijakan yang ada. Sama halnya dengan perjuangan suatu masalah untuk masuk dalam agenda kebijakan, dalam tahap perumusan kebijakan masing-masing alternatif bersaing untuk dapat dipilih sebagai kebijakan yang diambil untuk memecahkan masalah. Perumusan kebijakan unggul ini perlu kehati-hatian.

Demonstrasi yang marak terhadap RUU tersebut membuktikan bahwa agenda permasalahan permusikan belum dapat ditangkap penyusun kebijakan dengan baik. Sebaliknya, bagi pekerja musik permasalahan yang dijabarkan dalam RUU Permusikan bukan masalah penting bagi mereka, sehingga jawaban yang diberikan lewat RUU Permusikan tidak dianggap sebagai solusi dalam mengembangkan permusikan di Indonesia. RUU Permusikan mungkin merupakan hal yang amat penting bagi pemimpin-pemimpin politik, penasihatpenasihatnya, kelompok-kelompok berkepentingan, dan birokrasi karena merupakan produk yang penting untuk menunjukkan kinerja DPR yang 
terkenal rendah, namun para elite juga harus menyadari bahwa bukan rahasia bahwa tidak banyak dari para elite tersebut yang mempunyai kemampuan untuk memutuskan semua isu yang timbul, demikian juga terkait permusikan. Itulah sebabnya ada indikasi RUU tersebut bersifat inkrementalis, atau RUU Permusikan hanya berisi pengembangan kecil dari formula-formula yang dibuat di masa lalu yang menunjukkan keberhasilan untuk mendapatkan alternatif-alternatif pemecahan masalah.

Para pejabat publik harus menyadari bahwa mereka membutuhkan pertolongan, saran, kritik dari semua pihak yang ada dalam masyarakat karena proses penyusunan kebijakan publik yang menjadi kebutuhan masyarakat membutuhkan proses yang berat dan keterlibatan semua pihak. Kebijakan publik di Indonesia sebagai negara demokrasi sejatinya juga merupakan bidang yang harus dipikirkan semua orang, setiap warga negara sepatutnya diberikan kesempatan memberikan sesuatu yang berharga yang patut disumbangkan untuk kebaikan bersama. Pelibatan masyarakat dalam penyusunan kebijakan publik sangat penting khususnya para ahli kebijakan publik, dan sumbangan masyarakat yang tanpa interes politik itu penting untuk menghadirkan kebijakan yang unggul dan dapat diimplementasikan. Ruang lingkup kebijakan publik yang pertama itu adalah adanya partisipasi masyarakat untuk bersama-sama memikirkan cara-cara yang baik untuk mengatasi persoalan-persoalan masyarakat. Tanpa adanya partisipasi masyarakat dan rakyat banyak, maka kebijakan publik kurang bermakna dan sulit untuk dilaksanakan.

Dalam masyarakat Indonesia yang modern, demokratis, dan kekuasaan tertinggi berada di tangan rakyat, partisipasi dari masyarakat sangat penting sekali dalam urusan-urusan pemerintahan termasuk di dalam urusan kebijakan publik. Apabila RUU Permusikan dalam penyusunan agenda dan masalahnya melibatkan stakeholder yang luas, maka penolakan atas substansi RUU itu tidak perlu terjadi, karena masyarakat tentunya akan menyambut gembira sebuah kebijakan publik 
yang unggul yang akan membawa penyelesaian terhadap konflik yang terjadi dalam kehidupan masyarakat.

Hal lain yang dilanggar dalam proses perumusan RUU Permusikan adalah Undang-Undang Republik Indonesia Nomor 12 Tahun 2011 tentang Pembentukan Peraturan Perundang-undangan yang menjelaskan bahwa perundang-undangan harus didasarkan pada asas keterbukaan. Yang dimaksud dengan "asas keterbukaan" adalah bahwa dalam Pembentukan Peraturan Perundang-undangan mulai dari perencanaan, penyusunan, pembahasan, pengesahan atau penetapan, dan pengundangan bersifat transparan dan terbuka. Dengan demikian, seluruh lapisan masyarakat mempunyai kesempatan yang seluas-luasnya untuk memberikan masukan dalam Pembentukan Peraturan Perundangundangan. Hadirnya RUU Permusikan yang merupakan usulan Dewan Perwakilan Rakyat Indonesia seharusnya tidak boleh diartikan bahwa DPR adalah badan yang paling memahami permasalahan permusikan di Indonesia. Kebijakan publik permusikan seharusnya melibatkan semua pihak, sehingga kebijakan publik tersebut diyakini para pegiat musik dan seluruh masyarakat Indonesia sebagai jalan untuk menuju kehidupan yang dicita-citakan seluruh rakyat Indonesia.

\section{Evaluasi Materi RUU Permusikan}

Pasal 50 RUU Permusikan adalah salah satu pasal yang banyak menimbulkan kontroversi. Alasannya, pasal tersebut adalah pasal karet yang justru bisa membelenggu proses kreatif pekerja musik. Substansi proses kreatif menimbulkan perdebatan karena proses kreasi adalah domain individu menurut pekerja musik, tapi dalam RUU Permusikan proses kreatif yang adalah domain privat itu dapat diintervensi oleh pemerintah. Alasannya adalah apabila proses kreatif tersebut mengandung unsur: a. mendorong khalayak umum melakukan kekerasan dan perjudian serta penyalahgunaan narkotika, psikotropika, dan zat adiktif lainnya; b. memuat konten pornografi, kekerasan seksual, dan eksploitasi anak; c. memprovokasi terjadinya pertentangan 
antarkelompok, antarsuku, antarras, dan/atau antargolongan; d. menistakan, melecehkan, dan/atau menodai nilai agama; e. mendorong khalayak umum melakukan tindakan melawan hukum; f. membawa pengaruh negatif budaya asing; dan/atau RUU Permusikan g. merendahkan harkat dan martabat manusia. ${ }^{28}$

RUU Permusikan terkait materi proses kreatif terindikasi tidak mampu membedakan domain publik dan domain privat. Harus diakui bahwa membedakan secara tegas ruang publik dan privat tidak mudah. Tetapi dengan kehati-hatian, penyusunan agenda masalah yang menjadi dasar perumusan undang-undang permusikan dapat terbebas dari kontroversi yang mungkin ditimbulkan. Apabila penyusunan agenda masalah dilakukan dengan hati-hati, maka aturan proses kreatif yang mengijinkan pemerintah intervensi dalam ruang individu atau privat tentu tidak akan terjadi. Klaim bahwa hadirnya sebuah undang-undang untuk menata permusikan adalah sebuah keharusan sebagaimana dituangkan dalam naskah akademik RUU Permusikan, sesungguhnya tidak memiliki pijakan yang kuat, apalagi sampai memasuki domain individu atau privat yang seharusnya dihindari oleh pemerintah.

Penetapan aturan proses kreatif dalam RUU Permusikan jelas tidak sesuai dengan Undang-Undang Republik Indonesia Nomor 12 Tahun 2011 tentang Pembentukan Peraturan Perundang-undangan yang menjelaskan bahwa materi muatan Peraturan Perundang-undangan harus mencerminkan asas: ${ }^{29}$ a. pengayoman; Yang dimaksud dengan "asas pengayoman" adalah bahwa setiap Materi Muatan Peraturan Perundang-undangan harus berfungsi memberikan pelindungan untuk menciptakan ketentraman masyarakat. b. kemanusiaan; Yang dimaksud dengan "asas kemanusiaan" adalah bahwa setiap Materi Muatan Peraturan Perundang-undangan harus mencerminkan perlindungan dan

\footnotetext{
28 Naskah Akademik RUU Permusikan.

29 Undang-Undang Republik Indonesia Nomor 12 Tahun 2011 tentang Pembentukan Peraturan Perundang-undangan, Pasal 6, dan lihat penjelasannya.
} 
penghormatan hak asasi manusia serta harkat dan martabat setiap warga negara dan penduduk Indonesia secara proporsional. c. kebangsaan; Yang dimaksud dengan "asas kebangsaan" adalah bahwa setiap Materi Muatan Peraturan Perundang-undangan harus mencerminkan sifat dan watak bangsa Indonesia yang majemuk dengan tetap menjaga prinsip Negara Kesatuan Republik Indonesia d. kekeluargaan; Yang dimaksud dengan "asas kekeluargaan" adalah bahwa setiap Materi Muatan Peraturan Perundang-undangan harus mencerminkan musyawarah untuk mencapai mufakat dalam setiap pengambilan keputusan. e. kenusantaraan; Yang dimaksud dengan "asas kenusantaraan" adalah bahwa setiap Materi Muatan Peraturan Perundang-undangan senantiasa memerhatikan kepentingan seluruh wilayah Indonesia dan Materi Muatan Peraturan Perundang-undangan yang dibuat di daerah merupakan bagian dari sistem hukum nasional yang berdasarkan Pancasila dan Undang-Undang Dasar Negara Republik Indonesia Tahun 1945. f. bhinneka tunggal ika; Yang dimaksud dengan "asas bhinneka tunggal ika" adalah bahwa Materi Muatan Peraturan Perundangundangan harus memerhatikan keragaman penduduk, agama, suku dan golongan, kondisi khusus daerah serta budaya dalam kehidupan bermasyarakat, berbangsa, dan bernegara. g. keadilan; Yang dimaksud dengan "asas keadilan" adalah bahwa setiap Materi Muatan Peraturan Perundang-undangan harus mencerminkan keadilan secara proporsional bagi setiap warga negara. $h$. kesamaan kedudukan dalam hukum dan pemerintahan; Yang dimaksud dengan "asas kesamaan kedudukan dalam hukum dan pemerintahan" adalah bahwa setiap Materi Muatan Peraturan Perundang-undangan tidak boleh memuat hal yang bersifat membedakan berdasarkan latar belakang, antara lain, agama, suku, ras, golongan, gender, atau status sosial. i. ketertiban dan kepastian hukum; dan/atau yang dimaksud dengan "asas ketertiban dan kepastian hukum" adalah bahwa setiap Materi Muatan Peraturan Perundang-undangan harus dapat mewujudkan ketertiban dalam masyarakat melalui jaminan kepastian hukum. j. keseimbangan, keserasian, dan keselarasan; Yang 
dimaksud dengan "asas keseimbangan, keserasian, dan keselarasan" adalah bahwa setiap Materi Muatan Peraturan Perundang-undangan harus mencerminkan keseimbangan, keserasian, dan keselarasan, antara kepentingan individu, masyarakat dan kepentingan bangsa dan negara.

Melihat isi materi RUU Permusikan sebagaimana dijelaskan di atas dapat dipahami bahwa materi RUU Permusikan tidak memenuhi kebutuhan mereka yang terlibat dalam dunia permusikan, itulah sebabnya materi RUU Permusikan mendapat penolakan yang luas.

\section{Kesimpulan}

Agenda permasalahan permusikan di Indonesia sebagaimana dituangkan dalam RUU Permusikan yang merupakan inisiatif DPR dapat disimpulkan belum menjadi kebutuhan pekerja musik Indonesia. Itulah sebabnya kehadiran RUU Permusikan menimbulkan penolakan dari banyak pekerja musik di Indonesia.

RUU Permusikan belum dianggap sebagai kebutuhan permusikan di Indonesia karena penyusunan agenda persoalan permusikan di Indonesia tidak dilakukan dengan kehati-hatian, yakni dengan melibatkan stakeholder permusikan secara luas, selain itu waktu yang singkat dalam proses penyusunannya membuat isi materi RUU Permusikan menimbulkan kontroversi.

Materi RUU Permusikan secara khusus terkait aturan proses kreatif tidak mampu memisahkan domain privat dan domain publik secara bijak. Pasal yang berisi aturan proses kreatif ditolak oleh banyak pekerja musik sebagai instrumen yang dapat membelenggu kebebasan insan permusikan. Substansi RUU Permusikan tidak menjawab kebutuhan mereka yang menjadi sasaran kebijakan, karena kebijakan ini lebih merupakan ide elite, bukan permasalahan yang diangkat dari kehidupan masyarakat.

\section{Rekomendasi}

RUU Permusikan sebagai alternatif kebijakan direkomendasikan tidak 
dimasukkan dalam Program Legislasi Nasional karena penyusunan agenda permasalahan yang tertuang dalam RUU Permusikan kurang melibatkan mereka yang merupakan sasaran kebijakan. Cakupan RUU Permusikan yang amat luas membutuhkan peran serta masyarakat yang luas untuk merumuskan sebuah alternatif kebijakan sebagai jawaban terhadap persoalan masyarakat. Penolakan yang luas terhadap RUU Permusikan menunjukkan bahwa kebijakan itu bukanlah kebijakan unggul yang dapat diimplementasikan dengan baik. 